\title{
Os 40 anos sem Lukács e o debate contemporâneo nas ciências humanas*
}

\author{
The 40 years without Lukács and the \\ contemporary discussion in humanities
}

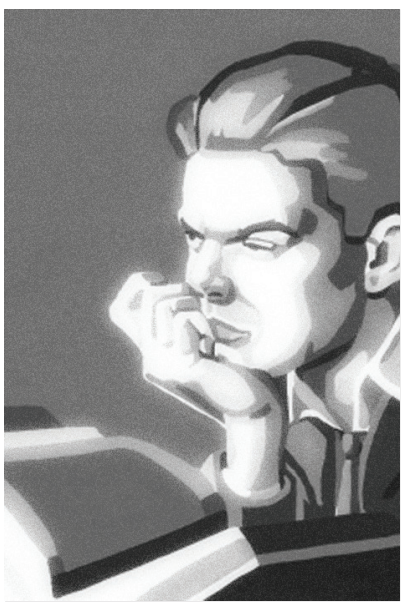

Rogério Castro**

Resumo: Após quatro décadas de sua morte, o filósofo marxista húngaro György Lukács tem sido um exilado da cultura contemporânea. O objetivo deste artigo é entender as causas de esse autor de tão densa envergadura ter a verdadeira fortuna crítica que constitui o seu espólio desprezada nos debates ora em curso nas ciências humanas.

Palavras-chave: Lukács. Ontologia do ser social. Trabalho. Pós-modernidade.

\begin{abstract}
After four decades of his death, the Hungarian Marxist philosopher György Lukács has been an exile from contemporary culture. The aim of this paper is to understand the causes of this author of so dense scale have true wealth which constitutes his estate overlooked in discussions now underway in the humanities.
\end{abstract}

Keywords: Lukács. Ontology of social being. Work. Postmodernity.

* Artigo submetido ao Programa de Pós-graduação em Serviço Social da Escola de Serviço Social da Universidade Federal do Rio de Janeiro (ESS/UFRJ) como requisito de ingresso no curso de Doutorado, no processo seletivo do ano de 2012. Para esta versão que ora vem a público, nosso agradecimento especial ao professor emérito José Paulo Netto (ESS/UFRJ) pelas correções e pelas cuidadosas observações.

** Doutorando em Serviço Social pela Universidade Federal do Rio de Janeiro-UFRJ, Brasil; mestre em Serviço Social pela Universidade Federal de Alagoas (UFAL). Em 2009 foi aluno externo do Programa de Pós-graduação em Serviço Social da ESS/UFRJ por intermédio do Programa Nacional de Cooperação Acadêmica (Procad/Capes). E-mail: rogeriocastrouesb@hotmail.com. 


\section{Introdução}

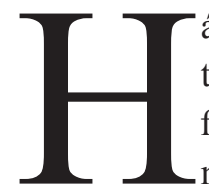

á exatos quarenta e dois anos, nos deixava talvez o espírito mais controverso que a tradição marxista viu passar "no breve século XX": o filósofo húngaro György Lukács. ${ }^{1}$ Nascido em Budapeste, Hungria, no dia 13 de abril de 1885, Lukács dedicou grande parte de suas oito décadas de vida ao intenso trabalho filosófico. Leu e conviveu com nomes consolidados na cultura europeia moderna, como Simmel e Max Weber. Ainda em sua juventude, adotou a perspectiva kantiana, rompendo em seguida com esta por influência de Hegel. Lia a emergente sociologia alemã e interessou-se, desde cedo, por crítica literária. São da primeira década do século que se iniciava as suas primeiras obras que iriam lhe dar certa projeção na cultura da época: A teoria do romance, A alma e as formas, A evolução do drama moderno. Mas o episódio mais significativo para a sua última grande virada filosófica veio da Rússia, no ano de 1917. Apesar de no primeiro momento rejeitar o bolchevismo por "um problema moral", um ano após ter estourado o Outubro Vermelho Lukács adere ao Partido Comunista da Hungria. É nele, inclusive, que vai revolucionar a cultura - na condição de comissário do povo - durante os pouco mais de quatro meses de vida da Comuna Húngara.

Após a vitória da contrarrevolução, Lukács vai se dedicar intensamente ao trabalho teórico e militante. Após publicar Tática e ética, Lukács vai lançar - no ano de 1923 - uma coletânea de ensaios que vinham sendo produzidos desde a derrota da Comuna Húngara em uma obra que iria ter grande impacto e logo em seguida passaria a integrar a lista dos livros malditos segundo o entendimento da Internacional Comunista (IC): História e consciência de classe. O nome de Lukács voltaria ao centro da polêmica seis anos mais tarde, quando vêm a público as famosas teses do camarada Blum (pseudônimo adotado por ele no PC húngaro). Forçado a renegar o conteúdo delas, de modo insincero conforme o mesmo irá admitir mais tarde, é durante seu primeiro exílio na URSS, entre os anos de 1930 e 1931, que ele irá fazer grandes descobertas e iniciar os primeiros passos que um estudioso seu, Guido Oldrini, chamaria de "virada ontológica". A partir daí que Lukács vai começar a romper com o seu marxismo abstrato, passar a ler Hegel com outros olhos, com a lupa de quem lera os escritos marxianos de juventude e os

1. Lukács faleceu exatamente no dia 4 de junho de 1971 (Netto, 1983). 
Cadernos filosóficos, de Lenin. Ao longo de toda sua trajetória daí para a frente, ele vai acompanhar, com certa preocupação, os rumos da URSS sob o efeito de graves deturpações do pensamento de Marx. E é, em grande medida, empenhado em corrigir tais erros, que o autor húngaro se lançará na monumental tarefa de redigir Ontologia do ser social, após, inclusive, ter acabado outro enorme empreendimento, a sua Estética.

Projetada para ser uma introdução a sua Ética, a Ontologia do ser social — que chega ao público brasileiro em seu primeiro volume ${ }^{2}$ — não tivera seus traços definitivos pelo fato de o autor vir a óbito antes do seu término. Segundo nos contam seus biógrafos, ele interrompera os trabalhos de acabamento para escrever os Prolegômenos para uma ontologia do ser social, uma espécie de obra introdutória, que recentemente também fora lançada no Brasil. ${ }^{3}$ Não obstante todos os percalços, estudiosos desta que seria a sua derradeira grande obra assinalam ser ela uma preciosa fonte de entendimento da tese marxiana do trabalho como momento fundante do ser social. Um dos mais atentos desses estudiosos, Sérgio Lessa afirma que por ter conseguido resgatar tal tese, com clareza e consistência inigualáveis, a Ontologia se constitui numa poderosa arma, nos dias atuais, para o combate às teses que falam do fim do trabalho, bem como aquelas que, ao tratar a essência humana como a-histórica, elevam a essência do homem burguês à essência burguesa do homem, como nos diz ele parafraseando Marx.

Apesar de nela estarem sedimentados de modo sistemático os principais complexos problemáticos tratados em vida por Marx (trabalho, reprodução, ideologia e alienação), mais especificamente no seu segundo volume, a proposta de renovação do marxismo, que conforme Nicolas Tertulian não sucumbiu aos escombros do muro de Berlim, quarenta anos após a morte de seu autor, não vingou. As razões para o esquecimento, ou como dirá José Paulo Netto, para Lukács se tornar um exilado na cultura contemporânea, um estranho no ninho, são muitas. Aqui, neste artigo, tentaremos expor de modo breve apenas algumas das várias que fazem com que seu nome seja sequer mencionado e sua imponente obra sequer referida. As transformações provocadas com o advento da era da informática; os estudos que apontam para uma abrupta diminuição do número de trabalhadores em atividades secundárias e o aumento progressivo no setor de serviços (terciário); os impactos

2. Lukács, G. Por uma ontologia do ser social I. São Paulo: Boitempo, 2012.

3. Lukács, G. Prolegômenos para uma ontologia do ser social: questões de princípios para uma ontologia hoje tornada possível. São Paulo: Boitempo, 2010. 
das interpretações do texto de Marx à luz de Althusser (e outros), aquilo que Leandro Konder chama de "Marx de segunda mão"; as influências que as descobertas dos psicanalistas Freud e Lacan a respeito da inconsciência tiveram no meio acadêmico; o tratamento da sociedade não mais como estrutura e sim como rede, não mais sólida e sim "líquida", entre várias outras.

O que procuraremos, por fim, nas linhas que se seguem, é tentar relacionar alguns conteúdos das teses de Lukács, contidos na sua Ontologia, com algumas das teses em voga hoje nas ciências humanas. Como a grande maioria delas entra em colisão com o núcleo fundamental do raciocínio lukacsiano, buscaremos, na medida do possível, apontar os pontos divergentes entre elas e o pensamento do autor húngaro, bem como, de algum modo, tentaremos proceder uma crítica que busque demonstrar as possíveis raízes dos seus equívocos.

\section{A perspectiva ontológica do ser e a reprodução da sociedade}

A primeira coisa que nos tem a dizer Lukács sobre a consideração do ser enquanto ser é que ele — diferente da velha ontologia escolástica — deve ser hierarquizado em graus, em conformidade como ele mesmo se apresenta como ser em geral, adequando-se à essência da realidade. Logo, a pergunta que deve ser posta é: qual grau do ser existe sem que sua existência dependa de outro? E ainda: qual grau para existir pressupõe a existência de outro? Estabelecendo o problema dessa forma, Lukács pôde afirmar que a natureza inorgânica é o grau de ser que existe independente da natureza orgânica e da própria sociedade. A natureza orgânica, ao contrário, só existe tendo como sua base de ser a natureza inorgânica, que constitui a base de ser inferior. Já o ser social depende desses dois graus que, juntos, perfazem o ser natural. A sua existência pressupõe a existência dos outros dois como sua base de ser.

Toda essa caracterização geral, conforme nos assegura o próprio autor, não está relacionada a propósitos valorativos; ela se resume simplesmente à constatação de um fato. Dessa hierarquização, Lukács pode então ordenar o ser segundo três aspectos que são referentes ao ser em geral: o problema da prioridade ontológica, da independência e dependência ontológica. ${ }^{4}$ Mas, então, o que diferenciaria cada grau do ser ou cada uma dessas esferas ontológicas? De acordo com o filósofo

\footnotetext{
4. Lukács, 1981, p. 166.
} 
húngaro, por não existir uma continuidade na natureza inorgânica diferente do "tornar-se outro", a reprodução seria o critério de distinção entre essa esfera e as outras duas superiores, a natureza orgânica e a social. Mas o que distinguiria a natureza orgânica do ser social? Numa palavra, a posição teleológica do trabalho, que é, segundo o autor, "a causa determinante desta diferença", ${ }_{5}^{5}$ não possui nenhuma analogia na natureza; é peculiar ao ser social.

A reprodução do ser biológico seria caracterizada por "relações relativamente estáveis" pelas quais, genericamente, poderíamos dizer que "eles reproduzem simplesmente a si mesmos", isto é, "seres viventes com a mesma constituição biológica". ${ }^{6}$ Por não constituir em sua interação com o mundo circunjacente complexos parciais mediadores, e por isso sua interação com o mesmo ser mínima, a reprodução do ser vivente na natureza orgânica coincide com a reprodução filogenética; dessa identidade imediata se elucida o mutismo do seu gênero. ${ }^{7}$

Ao tratar da analogia entre o biológico e o social, de o fato do traço comum à ambas as esferas ser a reprodução, Lukács nos mostra de que forma a esfera biológica tem como momento decisivo, do ponto de vista do desenvolvimento, a subjugação de categorias pertencentes a graus de ser inferiores.

Sem descer a detalhes, apenas observemos que o mundo vegetal se reproduz ainda mediante uma troca direta com a natureza inorgânica, enquanto o mundo animal já usa como alimento outros organismos; que, além disso, nas inter-relações dos animais com o seu ambiente as reações diretas e exclusivamente biofísicas e bioquímicas são substituídas por outras reações sempre mais complexamente mediadas (sistema nervoso, consciência). (Lukács, 1981, p. 147)

Apesar de inserida em novos nexos, a legalidade da esfera fundante não é inteiramente suprimida. Nas suas relações recíprocas com a esfera dependente, esta constitui categorias qualitativamente novas, com leis autônomas em relação àquelas da esfera fundante; mas é exatamente em sua novidade e autonomia que esta última é pressuposta em tudo pela esfera dependente. Disso pode se afirmar que nenhuma esfera dependente atinge sua conformação específica de um só golpe. Esta antes de atingir seus contornos mais definitivos, é resultado de um processo histó-

\footnotetext{
5. Ibidem, p. 147.

6. Ibidem, p. 147.

7. Castro, 2011, p. 41.
} 
rico através do qual "a perene reprodução das novas formas de ser produz, em um nível cada vez mais desenvolvido, autônomo [...] as categorias, as leis etc. especificamente características destas formas". ${ }^{8}$

O ser social compartilha com o biológico o fato de, do ponto de vista biológico, possuir características vitais, como nascer, viver, morrer, fases que não têm analogia com o ser inorgânico. Ele tem por base o homem, como base insuprimível enquanto ser vivente. Assim, a reprodução do ser social pressupõe, por um momento, a reprodução da sua base ineliminável — o homem. Só por um momento, porque a forma como essa reprodução da sua base biológica se dá é condicionada socialmente, pois "pela combinação da atividade social dos homens na reprodução da própria vida $[\ldots]$ nascem categorias e relações completamente novas [...] que... modificam também a reprodução biológica da vida humana". ${ }^{9}$ Lukács cita um exemplo dado por Marx nos Grundrisse $e^{10}$ para ilustrar tal situação. Segundo ele, a alimentação se constitui num fato inevitável para a reprodução humana; mas a fome que é saciada com carne crua, devorada por mãos, unhas e dentes, é diferente daquela que é satisfeita com garfo e faca; as formas de sua satisfação, portanto, são funções do desenvolvimento econômico-social.

Em outro setor da vida biológica, o da sexualidade, Lukács observa uma situação semelhante. Apesar de a atração entre os sexos não perder jamais o caráter biológico caracterizado pelos instintos, estes últimos, ao acolherem em si um número crescente de conteúdos advindos da intensificação das categorias sociais, mas sem com isso deixar de sintetizar-se organicamente com a atração física, possuem um caráter humano social que é diverso em relação a ela ${ }^{11}$ (a atração física). "[...] as suas formas fenomênicas [do desenvolvimento social] incidem profundamente até nos aspectos corporais e, da maneira de vestir à cosmética, influenciam de maneira decisiva o funcionamento dos instintos erótico-sexuais". ${ }^{12}$

8. Lukács, op. cit., p. 166-67.

9. Ibidem, p. 146.

10. Esse texto também já se encontra disponível ao público brasileiro graças à inédita tradução organizada pela editora Boitempo em parceria com a Editora UFRJ. Ver: MARX, K. Grundrisse: manuscritos econômicos de 1857-1858: esboços da crítica da economia política. São Paulo: Boitempo; Rio de Janeiro: Ed. UFRJ, 2011.

11. Dessa distinção, por exemplo, do caráter de socialidade das relações humano-sociais, do condicionamento social das mesmas, é que se pode concluir, por exemplo, que a essência do homem não é a-histórica, nem imutável.

12. Lukács, op. cit., p. 151. 
O ser social tem de específico a sua origem com o ato de trabalho. Por provocar mudanças externas e também internas, a reprodução do ser social assim se diferencia da reprodução da vida orgânica. De acordo com Lukács, o trabalho remete seus resultados para além de si mesmos. O que se desdobra necessariamente do seu ato é a fabricação de instrumentos, a exploração das forças naturais etc. Ao longo do seu processo reprodutivo, vão se verificando mudanças qualitativas no modo de realizá-lo, decorrendo disso aqueles pontos nodais "que transformam qualitativamente a estrutura e a dinâmica das sociedades singulares", ${ }^{13}$ que em certos casos irão significar verdadeiros saltos. Segundo o autor húngaro, o que vai possibilitar essas mudanças, do ponto de vista ontológico objetivo, é o fato de o trabalho teleologicamente, conscientemente posto, conter em si a possibilidade (dynamis) de produzir mais do que o necessário para a reprodução daquele que realiza o processo de trabalho.

Esta capacidade do trabalho de ir com seus resultados além da reprodução do seu executor cria a base objetiva da escravidão, antes da qual apenas existia a alternativa de matar ou adotar o inimigo feito prisioneiro. Daqui o caminho leva, através de várias etapas, ao capitalismo, onde este valor de uso da força de trabalho se torna a base de todo o sistema. (Idem, p. 136)

A divisão do trabalho é o produto orgânico necessário do trabalho. A cooperação, que surge em períodos ainda primitivos, é um tipo de divisão do trabalho. Segundo Lukács, a simples existência dessa divisão faz surgir a comunicação entre os homens - a linguagem. De acordo com ele, a linguagem "é um instrumento para fixar os conhecimentos e exprimir a essência dos objetos em-si através de pontos de vistas que se fazem sempre mais verdadeiros". ${ }^{14}$

No seu início, a divisão do trabalho é apenas ocasional, consistindo "num mero agir tecnicamente em comum no caso de determinadas operações ou cooperações". ${ }^{15}$ Conforme analisa o filósofo húngaro, é provável que se tenha decorrido um tempo relativamente longo até que a divisão do trabalho viesse a se consolidar em profissões e a se tornar uma estrutura social específica pondo-se diante dos indivíduos como uma forma já autônoma do ser social. Mas é somente

13. Ibidem, p. 136.

14. Ibidem, p. 136.

15. Ibidem, p. 154. 
na manufatura que há uma divisão do trabalho envolvendo as operações singulares, uma subdivisão do processo de trabalho enquanto tal, ainda que a motivação fosse provocada por um virtuosismo excepcional. Apenas com o advento da máquina é que surge uma subdivisão por ela determinada, dando início "à verdadeira e própria divisão do trabalho determinada pela tecnologia". ${ }^{16}$ Dessa forma, pode-se concluir que a divisão técnica do trabalho, que nos estágios superiores se apresenta de maneira tão evidente, é antes de tudo um efeito, e não uma causa. Ela se desenvolve daquela divisão de tarefas baseada na diferenciação biológica do gênero humano, que com o fato de o ser social se tornar cada vez mais puramente social, vai pondo em segundo plano o critério biológico desse princípio de diferenciação.

Engels revela que o lugar da mulher na vida social (matriarcado etc.) depende do fato de que o aumento da riqueza atribua às funções econômicas do homem um peso maior em relação àquelas da mulher, enquanto no estágio precedente a coisa estava invertida. (Idem, p. 138)

Dessa maneira, revela-se que uma relação tão elementar como a sexual acaba sendo, em última análise, determinada pela estrutura social em questão.

Uma das consequências da divisão do trabalho é o fato de ela ocasionar o surgimento de relações e ações puramente sociais. As posições que visam suscitar em alguém a vontade de operar determinadas posições teleológicas — as posições teleológicas de segundo tipo - são um exemplo (As posições teleológicas "primárias" são aquelas que visam a transformar um dado da natureza segundo finalidades humanas). O desenvolvimento da divisão do trabalho, segundo Lukács, por sua própria dinâmica espontânea, na linha desse processo de sobreposição do biológico pelo social, traz à luz cada vez mais categorias sociais puras, como o valor de troca. Conforme a necessidade com que a divisão do trabalho conduz a troca de mercadorias, o valor vai assumindo papel central na regulação da atividade econômica.

[...] o fato da troca, mesmo se, como Marx demonstra, se trata no início de uma troca - mais ou menos ocasional - entre pequenas comunidades e não entre os membros singulares, significa que já, de um lado, determinados valores de uso são produzidos em quantidade superior à necessidade imediata de seus produtores; e, por outro lado,

16. Ibidem, p. 140. 
que estes últimos têm necessidade de bens que eles não estão em condições de se abster por si com o próprio trabalho (Ibidem, p. 140).

Não tendo nenhuma relação com o ser físico, químico ou biológico, o valor de troca possui um caráter social puro. Por outro lado, mesmo sendo uma categoria social pura, o valor de troca apenas pode existir em associação com um valor de uso, ${ }^{17}$ a sua generalização na sociedade põe em relevo o tempo socialmente necessário como medida de sua grandeza concreta. Segundo Marx, diz o autor húngaro, o tempo de trabalho como regulador da produção é uma característica da reprodução em geral, apesar de na formação social capitalista assumir uma forma reificada. Ele se apresenta de modo diferenciado nas diversas formações, "nos diferentes níveis de consciência parcial ou de mera espontaneidade" 18 . Citando o exemplo de Robinson, segundo o autor, Marx teria escrito: "Precisamente a necessidade o constrange a distribuir exatamente o próprio tempo entre as suas diferentes funções", que ainda segundo Marx, seriam apenas "modos diferentes de trabalho humano". ${ }^{19}$ Numa família autossuficiente no quadro de uma economia feudal, também a corveia é medida com o tempo, da mesma forma como o trabalho produtor de mercadorias. O tempo de trabalho também desempenharia o seu papel no socialismo. Ele seria distribuído segundo um plano, e essa sua distribuição regularia "a proporção exata das diferentes funções do trabalho com as diferentes necessidades". E ainda seria medida de participação individual do produtor no trabalho comum. ${ }^{20}$

A divisão do trabalho se desenvolve do processo reprodutivo do trabalho. De acordo com Lukács, é um efeito do desenvolvimento das forças produtivas, o qual,

17. "O valor de troca é uma categoria social pura, sabemos, porém, que somente pode se tornar real em indissociável relação com o valor de uso. Este último, pelo contrário, é um dado da natureza socialmente transformado" (Lukács, p. 142). A ideia, como desenvolvida em Marx na sua teoria do valor-trabalho, de o valor das coisas não ser imanente a elas, e sim ser determinado socialmente, é o que se encontra de modo latente por detrás dessa fala de Lukács. O exemplo utilizado em $O$ capital, de o ouro ter seu valor (e sua importância) associado ao tempo de trabalho socialmente necessário para ser obtido, o que lhe dá o status de pedra preciosa, talvez sirva aqui para ilustrar a situação. Ver: CASTRO, R. Notas preliminares sobre a teoria do valor. In: CostA, G.; Prédes, R.; SouZA, R. (Orgs.). Crise contemporânea e serviço social. Maceió: Edufal, 2010.

18. Lukács, op. cit., p. 144.

19. A afirmação estaria n'O capital. In: MArX, K. O capital: crítica da economia política. São Paulo: Abril Cultural, 1983. v. I, t. I., p. 73-74. Há, também, uma nova edição dessa obra organizada pela Editora Boitempo.

20. Para mais informações, cf.: Ibidem, p. 75; e, também, o texto "Crítica ao Programa de Gotha". In: Antunes, R. (Org.). A dialética do trabalho. São Paulo: Expressão Popular, 2004. p. 101-124. 
por sua vez, "constitui um ponto de partida para um desenvolvimento ulterior". Nesse desenvolvimento, o processo de trabalho descobre e realiza coisas novas, novas necessidades e novas formas de satisfazê-las, mas também provoca na sociedade "uma divisão de trabalho não simplesmente técnica, mas também social"21. Mesmo tendo origem nos seus atos de trabalho, a divisão do trabalho, uma vez que exista, se coloca diante dos indivíduos como "potência social", assumindo um caráter autônomo de ser. O filósofo húngaro está se referindo a dois complexos que diferenciam fortemente a sociedade originalmente unitária: a divisão entre trabalho intelectual e físico (körperlicher Arbeit) e a divisão entre campo e cidade. O primeiro deles está contido em germe desde o início da divisão do trabalho, porque, como as posições teleológicas são de dois tipos, isto é, primárias e secundárias - as primeiras visam transformar um dado natural (objeto) com finalidades humanas e as segundas visam induzir outros homens a realizar uma posição teleológica que se quer que se realize - , quanto mais se desenvolve a divisão do trabalho, mais autônomas se tornam as posições de segundo tipo e "mais podem se desenvolver em um complexo por si da divisão do trabalho". ${ }^{22}$ Essa divisão entre trabalho intelectual e físico é potencializada quando, a partir de certo ponto, se verifica a divisão entre campo e cidade. Esta última, por concentrar a atividade industrial, passa a centralizar mais as tarefas ligadas ao trabalho intelectual, enquanto o campo é relegado dos progressos da cultura. "A humanidade, portanto, vai cada vez mais decisivamente se distanciando da sua situação de partida, quando a troca orgânica direta com a natureza imediatamente circundante envolvia, por inteiro, o trabalho de todos". ${ }^{23}$

Tais formas de divisão do trabalho se entrecruzam, no seu desenvolvimento, com a que do ponto de vista histórico é a mais importante: a da diferenciação das classes. A origem dessa diferenciação está no fato de o valor de uso da força de trabalho poder produzir mais do quanto necessita para reproduzir a si mesma. Logo, é o desenvolvimento da produção que vai determinar, ainda que em termos de interação, o tipo de diferenciação, da função e perspectiva social das classes.

As condições econômicas haviam primeiro transformado a massa da população do país em trabalhadores. A dominação do capital criou uma situação comum, interesses comuns para esta massa. Desta forma, esta massa já é uma classe nos confrontos do

21. Lukács, op. cit., p. 154-55.

22. Ibidem, p. 155.

23. Ibidem, p. 157. 
capital, mas não ainda por si mesma. Na luta... esta massa se reúne, se constitui em classe por si mesma. (Marx, K. A miséria da filosofia, apud Lukács, 1981, p. 159)

Lukács nos diz que com a primeira divisão em classes na sociedade levada a cabo pela escravidão, junto com a qual além dos antagonismos entre escravos e senhores surgem também aqueles entre credores e devedores etc., os conflitos que daqui surgiram, junto com os advindos da circulação de mercadorias, do comércio, tiveram de ser regulamentados socialmente por meio de uma jurisdição conscientemente posta, não mais apenas tradicional. $\mathrm{O}$ autor húngaro observa que simultaneamente ao aparecimento da esfera jurídica na vida social, se verifica o surgimento de um grupo de pessoas que recebe o mandato social de impor por intermédio da força os objetivos desse complexo. Surge, então, uma força pública que organiza a si mesma como poder armado, não coincidindo mais diretamente com a população. Apesar de vir no primeiro plano aquela luta de classe que vem das formas fundamentais de apropriação do trabalho excedente, Lukács afirma que não devem ser desprezados os antagonismos de classe de outro tipo, surgidos pelo trâmite das mediações econômicas. Quando os antagonismos sociais já adquiriram formas mais mediadas, diz o autor, reduzir, entretanto, a regulamentação do agir "ao puro uso da força significaria chegar, sem mais, à destruição da sociedade" ${ }^{24}$. Entra em cena, então, aquela complicada unidade entre força explícita e força disfarçada, revestida com os trajes da lei, cuja expressão é a forma jurídica.

Os homens armados engelsianos cedem o lugar à eventualidade weberiana de que em caso de conflito venham homens com armas na mão, o que diz claramente como, não obstante todas as variações de alguma forma absolutamente irrelevantes, a estrutura aqui indicada se reproduz substancialmente tal e qual ao longo da história. (Idem, 243)

O sujeito do dever de julgar os vários resultados da práxis humanas, isto é, de estabelecer se estes são lícitos ou delituosos, é o Estado. Este além de possuir o monopólio desse juízo, detém ainda o monopólio "legítimo e exclusivo da força física". Lukács afirma, no entanto, que este poder de decisão seria "um reflexo inadequado do processo social". Segundo ele, como tem que ter necessariamente um caráter prático, todo estabelecimento jurídico possui um duplo caráter. Por ter que ser uma fixação ideal, não acolhedora de contradições, detentora de univoci-

24. Ibidem, p. 207. 
dade lógica, tal "sistema, de fato, não se desenvolve como reflexo desta [do terreno da realidade], mas como manipulação que a homogeniza em termos abstrato-ideais" ${ }^{25}$ Por outro lado, do ponto de vista do sistema, a ausência de contradições "decretada oficialmente" é mera aparência. Contudo, se vista segundo o ponto de vista da ontologia do ser social, essa forma de regulamentação é, no concreto, socialmente necessária, "pertence ao ser-precisamente-assim da sociedade na qual opera" ${ }^{26}$ Por conta disso, a sua compacticidade sistemática é ilusória, pois o estabelecimento do que é lícito ou não e o seu ordenamento em um sistema não está ancorado na realidade em si, mas "na vontade da classe dominante em ordenar a práxis social segundo os próprios desígnios". ${ }^{27}$

Conforme nos assegura o filósofo húngaro, toda tentativa de "sonho de justiça" não pode se situar, na verdade, nunca para além de uma concepção econômica de igualdade. Isto quer dizer que como só é possível igualar trabalhos concretamente distintos entre si apenas no plano abstrato, o critério utilizado para igualar tais trabalhos diversos a uma grandeza comum (ou equivalente) é o tempo de trabalho socialmente necessário. Dizendo de outro modo: como o que determina o valor das grandezas de duas mercadorias é o tempo de trabalho social médio, como este é o critério que as iguala, fazem-nas ter o mesmo valor, podemos afirmar que essa igualdade realizada na circulação de mercadorias só pode ser obtida quando dois produtos que no concreto são diversos são reduzidos a trabalho indiferenciado, isto é, a um mesmo quantum de trabalho (abstrato), que é medido pelo tempo. ${ }^{28}$ É dessa compreensão geral que Marx vai afirmar, segundo Lukács, que o direito, também no socialismo, é um direito da desigualdade, como todo direito. Ele considera como igual, reduz a uma medida comum, o que no concreto é desigual (as capacidades individuais de rendimento); logo, não pode deixar de ser este direito igual um direito desigual para trabalho desigual - a diferença aqui é que todos seriam considerados segundo um único ponto de vista, o de todos serem operários. Por conta disso é que a única possibilidade de superação desse dilema no concreto ${ }^{29}$, e o di-

25. Ibidem, p. 215.

26. Ibidem, p. 215.

27. Ibidem, p. 215.

28. Vale salientar que esse tempo social médio surge como categoria econômica espontaneamente no devir da sociedade. Ver mais sobre a teoria do valor-trabalho em Castro (2010a).

29. Segundo Lukács (1981), “a discrepância entre o conceito jurídico de igualdade e a desigualdade da individualidade humana” (p. 219). 
reito tal como conhecemos assim conhecer a sua perspectiva de extinção, seria quando a sociedade (comunista), já totalmente reestruturada, se organizasse segundo o lema: "De cada um segundo as suas capacidades, a cada um segundo as suas necessidades". ${ }^{30}$

O autor da Ontologia afirma que o complexo jurídico é um fenômeno dependente do desenvolvimento econômico. Contudo, pode atingir uma relativa autonomia em relação ao regime então dominante, a ponto inclusive de ser considerado "uma espécie de Estado no Estado" (teoria da divisão dos poderes). Apesar disso, esta autonomia nunca pode concretamente se desvencilhar dos limites oriundos das concretas relações econômicas.

O fato de que os espaços que de tal modo são criados repousem, por sua vez, sobre relações reais de força entre as classes, não impede que o direito permaneça uma espécie de Estado no Estado, mas simplesmente determina concretamente o caráter e os limites de tal relação. (Lukács, 1981, p. 222)

Outro ponto destacado é com relação às tarefas especiais que são criadas com a expansão quantitativa e qualitativa da divisão social do trabalho. Tais deveres teriam a função particular de serem formas de mediação específicas entre complexos singulares, assumindo, com isso, uma peculiar estrutura interna. Contudo, de acordo com o autor, como as necessidades do processo enquanto complexo conservam a sua prioridade ontológica, estas "determinam tipo, essência, direção... das funções exercidas por tais complexos ontológicos mediadores". ${ }^{31}$

Mas, justamente porque o funcionamento correto num nível superior do complexo total atribui ao complexo mediador funções parciais específicas, este assume certa autonomia - que surge por necessidade objetiva —, um certo modo autônomo e específico de reagir e agir, do qual, exatamente por esta sua especificidade, a totalidade não pode prescindir na sua reprodução (Lukács, 1981, p. 223).

30. Tal discussão se encontra em Marx no texto "Crítica ao Programa de Gotha” (op. cit.), p. 105-111.

31. Estas colocações de Lukács talvez ajudem a iluminar o debate existente no Serviço Social acerca da "relativa autonomia" no exercício da atividade desse profissional. Uma das animadoras dessa ideia, Marilda Iamamoto, defende esta tese no seu A prática como trabalho e a inserção do assistente social em processos de trabalho. (2004) e também em Serviço Social em tempo de capital fetiche. Capital financeiro, trabalho e questão social. São Paulo: Cortez, 2007; a citação de Lukács (op. cit.) se encontra na pág. 223. 
O complexo social do direito, portanto, seria, segundo Lukács, um complexo conscientemente posto, que surge junto com a sociedade de classes. Para se reproduzir, esse complexo vai exigir na divisão social do trabalho uma figura própria com a função de regular o complexo de problemas advindo da luta em torno da posse do trabalho excedente: os jurisperitos. De natureza diversa, outro complexo analisado pelo autor é o da linguagem. Surgido de modo espontâneo desde quando a necessidade de se comunicar tornou-se imperativa, o complexo da linguagem é universal e a sua reprodução não depende - necessariamente - de um grupo de especialistas que ditem as regras de como esse complexo deva se reproduzir.

Só com a descoberta e a produção do novo, daquilo que até aquele momento era ignorado, no processo de trabalho, na utilização de seus produtos etc., se apresentam na consciência conteúdos novos e multiformes que exigem, taxativamente, uma comunicação. (Idem, p. 192)

A linguagem é, segundo Lukács, o instrumento social que serve para dar curso às posições teleológicas de segundo tipo. A sua finalidade última é a ação genérica do trabalho. Ao fazê-la nascer pelo novo por ele produzido, o homem cria um médium para o contato inter-humano que se encontra no nível da sua generalidade. A tendência objetiva que vai advir do caráter genérico do homem vai se repercutir na linguagem. De acordo com o autor, desde o início nela atua uma intenção objetiva da parte do sujeito rumo à legalidade do objeto que se quer designar. De modo que cada palavra irá exprimir sempre "a generalidade do objeto, o gênero, a espécie, não o exemplar singular". ${ }^{32}$ Por outro lado, uma tendência na direção oposta, isto é, de aproximação do caso singular, também será verificada. "A expressão 'tu és um vigarista' pode querer indicar, em algumas circunstâncias, um juízo positivo, do mesmo modo pelo qual 'fez novamente uma bela coisa' pode significar censura". ${ }^{33}$ Apesar disto, desses matizes, reservas etc., a estrutura de fundo pela qual a ação particular e o seu autor são enquadrados em determinada classe de comportamento permanece mantida.

De acordo com Lukács, a linguagem é sempre, em essência, ao mesmo tempo, "cópia e expressão daquilo que o gênero, na sua autorrealização, alcançou, de fato, a

32. Lukács, op. cit., p. 192.

33. Ibidem, p. 195. 
cada vez" ${ }^{34} \mathrm{O}$ seu caráter espontâneo não anula o fato de ela ter origem nas posições teleológicas individuais. A legalidade que rege o ser social, explica ele, teria uma dupla face: por um lado, há uma lei irrefreável que o conduz a graus de sociabilidade cada vez mais puros; por outro, as tendências que nele operam, apesar de se originar nas posições teleológicas individuais, não têm um caráter teleológico. Isso se explicaria pelo fato de a síntese social realizar mais do que estava contido originalmente em cada posição individual. "[...] já que toda posição teleológica coloca em movimento cadeias causais que são mais numerosas e diversas do quanto se desejava com aquela posição, a síntese social vai além de todas as posições singulares". ${ }^{35}$

Como todos os verdadeiros complexos no interior do complexo do ser social, a linguagem tem um desenvolvimento autolegal. Contudo, a "autolegalidade possui um caráter histórico-social variado". Segundo o autor, a linguagem dependeria das transformações da vida social, mas, ao mesmo tempo, o seu desenvolvimento seria determinado por sua própria autolegalidade. "O desenvolvimento da linguagem procede por leis próprias, mas em uma articulação contínua, quanto aos seus conteúdos e às suas formas, com a sociedade de cuja consciência ela é órgão". ${ }^{36} \mathrm{O}$ que a princípio parece um desvio da legalidade, diz ele, mais tarde pode ser o germe de uma nova legalidade, ou a modificação daquela precedente. Essa dupla determinação, no plano do ser, por parte das esferas da vida heterogêneas entre si, é, portanto, para a linguagem, a base real do seu ser e devir.

Na real transformação ontológica do em-si mudo da natureza orgânica no para-si não mais mudo do ser social, Lukács afirma que o entendimento desse contraste é algo mais abrangente do que "a contraposição psicológica ou gnosiológica entre consciente e não consciente". ${ }^{37}$ Ele diz que partindo do ato originário da sociedade - o trabalho - a diferença qualitativa entre as duas esferas ontológicas se faz nítida. Apesar de no seu início não ser plenamente consciente, o ato de trabalho - nos seus primórdios — não é totalmente não consciente: “[...] o trabalho é impossível sem consciência, mas essa no início não ilumina além do ato de trabalho singular". A posição teleológica do trabalho não é consciente do ponto de vista do gênero. De acordo com o autor, o fato de o trabalho encarnar a generalidade do homem não quer dizer que nos atos de trabalho haja consciência do nexo

\footnotetext{
34. Ibidem, p. 199.

35. Ibidem, p. 150.

36. Ibidem, p. 201.

37. Ibidem, p. 182.
} 
real, apesar de ele ser, já como ato do indivíduo, por essência, social. É por meio do trabalho que se realiza a autogeneralização social do homem, "a elevação objetiva do homem particular à generidade". ${ }^{38}$

A caracterização da consciência, portanto, só pode ser corretamente feita se a sua apreensão se der na processualidade do processo, isto é, se o seu surgimento e o seu desenvolvimento forem considerados como algo processual, gradual e continuativo, e não como surgidos de um só golpe.

A razão pela qual tal caminho seria errado não está na consciência enquanto tal, mas no seu objeto, no processo objetivo, do qual a consciência é produto e, ao mesmo tempo, expressão realizada. (Ibidem, p. 184)

A consciência não surge no ser social sem correlação com o processo objetivo; ela é o órgão dessa nova forma de continuidade. Ora, como a consciência é "produto e expressão realizada" do processo objetivo e como ela é o veículo sem o qual essa nova forma de continuidade não pode existir, pode-se afirmar que entre consciência e objetividade social há uma relação de mútua exclusão ou de interdependência. No entanto, afirmar isto não significa dizer que haja uma relação de identidade entre sujeito e objeto; ao contrário, conforme afirma Lukács, a realidade objetiva, inclusive a social, existe independente da consciência dos homens.

[...] se a reprodução social, em última análise, se realiza nas ações dos indivíduos — no imediato a realidade social se manifesta no indivíduo —, todavia estas ações, para se realizarem, se inserem, por força das coisas, em complexos relacionais entre homens, os quais, uma vez alcançados, possuem uma determinada dinâmica própria, isto é, não só existem, se reproduzem, operam na sociedade independente da consciência dos indivíduos, mas dão também impulsos mais ou menos, diretamente ou indiretamente, determinantes às decisões alternativas. (Idem, p. 156)

O papel da consciência como órgão da continuidade é conservar em si o patamar atingido e servir de plataforma - ou ponto de apoio - em direção a objetivações futuras. Como ela representa determinado estágio de desenvolvimento do ser e, por conseguinte, os limites deste representam seus próprios limites, ela só pode objetivar - em última análise - em observância a tal estágio. "[...] no momento em que a consciência surge como médium, como portadora e depositária da continuidade, este [o ser social] alcança a um ser-para-si que não existe nas outras

38. Ibidem, p. 182. 
esferas". ${ }^{39}$ Esta seria —, portanto, uma função ontológica da consciência, através da qual a peculiaridade do ser social em relação às outras formas de ser é manifestada.

De acordo com Lukács, toda reprodução filogenética requer, primariamente, a reprodução ontogenética dos exemplares singulares, que em sentido imediato encarnam o ser. Seja no âmbito de um processo de permanência e mutações de espécies, seja no âmbito de um complexo de complexos constituído pela práxis humana, a reprodução ontogenética do singular possui prioridade ontológica no que tange a outras manifestações da esfera de ser de que se fala. ${ }^{40} \mathrm{E}$ afirmar isso de novo, se resume estritamente à verificação de um fato, e não uma tomada de posição valorativa.

Na sociedade, o complexo da reprodução ontogenética surgido com a progressiva sociabilização da existência humano-biológica é a economia. Com o recuo das barreiras naturais e com as atividades humanas assumindo cada vez mais uma feição social, a resistência intelectual em reconhecer a prioridade ontológica da esfera econômica frente às outras aumenta.

Ainda pior é quando são colocadas em jogo, por exemplo, motivações psicológicas. Pois é sem mais evidente que quanto mais são complexas, mediadas, as estruturas sociais que colocam em movimento a produção e o consumo, através dos quais se realiza a reprodução ontogenética de qualquer indivíduo singular, tanto menos está presente a consciência de tal reprodução e da sua prioridade ontológica, frente a todas as outras manifestações vitais. (Idem, p. 234)

O autor nos diz que, a exemplo da esfera jurídica, na dependência última da economia enquanto complexo da reprodução primária, seria impossível um complexo, para se tornar útil, se desenvolver sem criar nele mesmo métodos próprios de funcionamento e de organização. Contudo, afirmar isso, conforme ele categoricamente nos assinala, não é dar por certo que um complexo parcial possa se desenvolver de maneira "independente da estrutura e da dinâmica evolutiva do respectivo estágio da sociedade". O fetichismo da técnica - que segundo nos diz ele passa a não ser entendida como um momento parcial do desenvolvimento econômico — advém do fato de ela ser considerada, especialmente hoje, ${ }^{*}$ como fato

39. Ibidem, p. 186.

40. "A fim de que todas aquelas complicadíssimas manifestações vitais, que no seu complexo constituem o ser social, se tornem realidade, antes de tudo o ser vivente homem deve poder reproduzir biologicamente a sua existência biológica" (Ibidem, p. 233).

* A referência aos dias de hoje deve ser relacionada ao período em que a Ontologia foi escrita, nos anos 1960 . 
autônomo, insuperável, da época moderna, semelhante à crença dos cidadãos da pólis na época do ouro de um poder fatal da natureza sobre os homens.

Para Lukács, o caráter da economia enquanto momento predominante nos confrontos com os demais complexos sociais significa que as variadas formas de apropriação do trabalho excedente ao longo da história - produzidas pelo desenvolvimento econômico - constituem, no particular, a característica decisiva de cada grande época. "Aquilo que neste desenvolvimento desigual e contraditório se conserva como sua substância na perene mudança se reduz ao fato da apropriação", diz ele. A diferença do socialismo em relação às formações precedentes se resume ao fato de que nele é a sociedade no seu todo o único sujeito da apropriação. Assim, portanto, ele distingue tal entendimento daqueles que afirmam existir uma independência total dos complexos singulares para com a economia.

A representação idealística-fetichizante, tão frequente nas ciências históricas e sociais, de uma independência absoluta dos complexos singulares, de um lado parte de uma representação restrita e reificada do econômico; as suas rigorosas legalidades, efetivamente presentes, à luz desta reificação fazem esquecer que ele não constitui uma realidade somente objetiva, indiferente para com a nossa existência, como por exemplo, a natureza inorgânica, que, ao invés, ele é a síntese legal daqueles atos teleológicos que cada um de nós realiza continuamente e continuamente deve realizar — sob pena da ruína física - ao longo de toda a sua vida. (Idem, p. 245)

O autor reconhece os efeitos devastadores da renúncia dos postulados dialéticos realmente existentes na realidade social pelo marxismo vulgar e a substituição da dependência do processo complexivo do desenvolvimento econômico por uma dependência mecânica, fato que o fizera incorrer no campo da gnosiologia. No entanto, a impostação lukacsiana diante deste propõe-se a ser um tertium datur.

\section{0 debate contemporâneo nas ciências humanas}

Uma das contraposições mais bem elaboradas, nas visões de Sérgio Lessa e Carlos Nelson Coutinho ${ }^{41}$, à tese do ser social fundado pelo trabalho defendida

41. Lessa em Mundo dos homens: trabalho e ser social (São Paulo: Boitempo, 2002) e Carlos Nelson em Intervenções: o marxismo na batalha das ideias (São Paulo: Cortez, 2006). 
por Lukács, e cuja recorrência no debate atual é bastante comum, é a de Habermas na sua Teoria do agir comunicativo. De acordo com Lessa, partindo da consideração de que o ato de trabalho já existe nos hominídeos, Habermas refuta o fato de ser este o diferenciador decisivo da relação entre natureza e sociedade, e diz que o que distingue uma da outra é a articulação entre trabalho e linguagem ${ }^{42}$. Para Coutinho, o equívoco de Habermas reside no fato de ele inverter a relação de "os homens se comunicam porque trabalham" para "os homens trabalham porque se comunicam".

O professor André Lemos diz que para Habermas a parte instrumental que dominou a razão na vida moderna precisaria ser superada em seus excessos. Convergindo com Lessa, Lemos afirma que o caminho apontado por Habermas seria o de por meio da razão comunicativa se chegar ao consenso e corrigir então "o processo filosófico da modernidade". ${ }^{43} \mathrm{O}$ problema deixaria de ser localizado e solucionado a partir do concreto e ganharia uma dimensão resolutiva exclusivamente subjetiva. Segundo Lemos, teria dito o filósofo alemão: "no lugar de renunciar à modernidade e a seu projeto, deveríamos tirar lições dos desvios que marcaram esse projeto e dos erros cometidos por abusivos programas de superação". ${ }^{44}$

Habermas buscou descobrir a "lógica própria" (ou as regras) através da qual, segundo ele, o agir comunicativo se processava. Na visão apresentada em Para a reconstrução do materialismo histórico, as "estruturas da intersubjetividade produzidas linguisticamente" são constitutivas para "os sistemas de sociedade", de modo que formam o "tecido de ações comunicativas". ${ }^{45}$ De acordo com Lessa, como seriam as estruturas intersubjetivas a base para as ações comunicativas, a referência ontológico-objetiva no trabalho deixa de ter centralidade, dando lugar ao conceito que será empregado na sua Teoria da ação comunicativa de "mundo da vida". Este conceito, e não mais a relação fala/trabalho defendida anteriormente, é que será agora o momento fundante da sociabilidade, nas palavras de Lessa. Nesse último texto, a racionalidade de uma emissão depende da confiabilidade do saber que encarna, uma vez que a racionalidade estaria, segundo Habermas, mais ligada à

42. Esta visão seria defendida pelo autor num ensaio publicado numa coletânea que circulou pelo Brasil sob o título Para a reconstrução do materialismo histórico.

43. Lemos, A. Cibercultura, tecnologia e vida social na cultura contemporânea. 3. ed. Porto Alegre: Sulina. 2007. p. 61-2.

44. Esta fala, segundo Lemos, estaria no texto "Modernité: um projet inachevé". Critique, Paris, n. 413.

45. Segundo Lessa, essa coletânea foi publicada pela editora Brasiliense, em 1990. O excerto se encontra na p. 14. 
forma com que os sujeitos capazes de linguagem e ação fazem uso do conhecimento. Vinculando suas manifestações à crítica, cada juízo dos sujeitos agentes para ter validade objetiva deverá necessariamente passar por "via de uma pretensão transubjetiva de validade", onde deverá ter o mesmo significado tanto para o observador como para o agente. "A verdade ou a eficácia são pretensões deste tipo", ${ }^{46}$ diz ele. A racionalidade comunicativa, portanto, refere-se à capacidade de se gerar consensos através da fala argumentativa. Sem nenhum nódulo concreto a ser desfeito, o debate habermesiano ganha uma dimensão unicamente subjetiva, semelhante à do cidadão-abstrato. ${ }^{47}$

O sociólogo brasileiro Renato Ortiz, no seu Mundialização e cultura, traz uma visão muito difundida nas ciências sociais a respeito da tese sobre a economia enquanto complexo primário da reprodução social. Segundo esse autor, esse pensamento, apesar de fazer avançar na compreensão do world-system, é marcado por um acentuado viés economicista. De acordo com ele, como "a base econômica constitui a unidade privilegiada de análise, as manifestações políticas e culturais surgem como seu reflexo imediato". ${ }^{48}$ Ainda segundo Ortiz, essa forma de se compreender os fenômenos sociais traria consigo um raciocínio (para ele) já conhecido: "A sociedade seria formada de uma infraestrutura econômica e de uma superestrutura ideológica. O material do piso compreenderia e determinaria a parte superior dessa construção arquitetônica" ${ }^{49}$ Outro influente pensador atual, o francês Pierre Lévy, na sua proposta de ecologia cognitiva ("para além do sujeito e do objeto"), não deixa de salientar que, apesar de ter sido o pioneiro no trato mais analítico do funcionamento coletivo, Marx teria dado uma interpretação "bastante grosseira" a esse fenômeno histórico, "recorrendo ao interesse de classe e usando a metáfora do reflexo da infraestrutura na superestrutura". ${ }^{50}$

46. Cf. apud. Lessa, 2002, p. 228-29.

47. Em Educação, cidadania e emancipação humana, Ivo Tonet (2005) retoma a discussão feita por Marx nas Glosas. O cidadão moderno se encontra cindido, diz Marx; se por um lado, ele ganhou a liberdade política consubstanciada na forma jurídica; por outro ele se encontra limitado em suas condições de se prover por si. Daí a clássica frase de a liberdade da sociedade civil moderna ser a liberdade do cidadão burguês, detentor exclusivo dessas condições (e por meio das quais constitui o capital pela exploração do trabalho alheio). Dela também se explica o porquê de a forma ser jurídico-abstrata, isto é, por não ser efetiva na prática (a igualdade), do ponto de vista concreto (p. 116-21); sobre o duplo caráter do direito, ver supra. Ver também: Castro (2010b).

48. Ortiz, 1996, p. 22.

49. Ibidem, p. 22.

50. Lévy, 1993, p. 140. 
Ora, conforme assinalado no tópico anterior, para esses dois autores ser e posição de valor são a mesma coisa. Isto é, análise ontológica e posição dentro de uma hierarquia de valor, a diferença crucial entre elas posta por Lukács na sua Ontologia, são desconsideradas. É como se Marx — por vontade própria, de maneira arbitrária - "privilegiasse" a esfera econômica, impusesse à realidade social uma determinação férrea e, com isso, "recorresse ao interesse de classe" com o intuito de fazer da "luta de classes o motor da história". ${ }^{51}$ Em suma: é como se ele se antecipasse aos fatos da realidade com a intenção de forçá-los a fornecer para sua análise as respostas previamente desejadas. Ora, como nos diz Lukács na sua Ontologia, é exatamente a operação inversa que Marx faz. Partindo da realidade objetiva - do ser hierarquizado em graus conforme a essência da realidade, segundo os critérios de prioridade ontológica, dependência e independência ontológica que ordenam as esferas de ser - , do mundo exterior real e existente independente da consciência dos indivíduos, que surgem junto com a esfera ontológica do ser social após a posição teleológica do trabalho, Marx teria descoberto o fundamento último a partir do qual a sociedade se estrutura. Isto é, a partir da generalidade do ato de trabalho, da capacidade de ele ir com seus resultados para além de si mesmos, de o seu executor imediato poder produzir mais do quanto necessita para se reproduzir, enfim, do seu processo reprodutivo, surge o excedente de produção e da luta em torno da sua posse a sociedade vai conhecer a sua primeira diferenciação de classes: escravos e senhores. Daqui, como dito anteriormente, vai surgir a necessidade de uma jurisdição conscientemente posta, não mais transmitida, a força pública que não mais coincide diretamente com a população e o sujeito do dever de julgar se são lícitos ou não os vários resultados da práxis humana - o Estado. Desse valor de uso da força de trabalho é que, através de várias fases, vai se chegar ao sistema capitalista, onde agora o mecanismo de exploração do trabalho alheio assume outra conotação, com o capitalista comprando o valor de uso da mão de obra "livre". Portanto, é dessa forma que o desenvolvimento da sociedade — objetivamente - ocorrera até aqui. Por exemplo: a gênese das classes não são designações arbitrárias. Estas surgem na sociedade a partir do momento em que aparece objetivamente o excedente de produção e a luta em torno da propriedade deste, antes do que existia o dilema de atacar o inimigo ou ser feito prisioneiro por ele, marca o aparecimento da divisão em classes - escravos e senhores -, bem como de outros antagonismos (credores e devedores etc.). Se o homem, junto com a sua

51. Ibidem, p. 137. 
base biológica, para poder se reproduzir em sociedade (isto é, fazer todas as manifestações que são peculiares ao seu gênero) precisa antes de tudo reproduzir a sua condição de existência — ou seja, a sua base biológica —, não é essa uma impostação subjetiva, mas sim uma condição ontológica, que não teria nada que ver com posição de valor; resumiria-se apenas à constatação de um fato. Seria nisso, portanto, nessa determinação objetiva, que estaria fundada a tese marxiana segundo a qual o complexo da reprodução ontogenética do homem surgido com a progressiva sociabilização da sua existência humano-biológica, isto é, a economia, detém prioridade ontológica frente às outras manifestações da vida humana, aos outros complexos sociais.

Diferente em tudo dessas interpretações — que reconhecem de forma correta inclusive que tais caminhos conduzem a um reducionismo, mas se contentam equivocadamente em reduzir o legado ontológico marxiano a ele - , alguns complexos sociais, como dito, para funcionar em termos ótimos atingem relativa autonomia da qual, exatamente por fazer funcioná-los de forma útil, a totalidade não pode prescindir. Logo, estaria fora de propósito, à luz de Marx, considerar que a "esfera da política seria assim a mera extensão do nível infraestrutural". ${ }^{52}$ Aliás, Lukács ainda fala que não é o mesmo, sempre e em toda parte, o peso concreto do momento predominante, podendo variar também a cota de eficácia exercida pelos complexos numa dada interação, condenando, com isso, posturas niveladoras ideais. Vejamos como ele se refere ao peso da luta de classes na história, posto por Lévy com assoberbada convicção irônica:

[...] as classes, e a sua luta no curso do desenvolvimento econômico, modificam este último muito mais incisivamente que a interação com qualquer outro complexo. Segue-se, certamente, que é o desenvolvimento econômico que determina, em última análise, as relações de força entre as classes e, portanto, também o êxito das suas lutas, mas só em última análise porque - como veremos mais à frente - quanto mais desenvolvidas, em sentido social, são as classes, quanto mais o seu ser social afastou as barreiras naturais, tanto maior é o papel do fator subjetivo nas suas lutas, a transformação da classe em-si em uma classe para si, e isto não diz respeito somente ao seu grau de desenvolvimento geral, mas também, aos aspectos singulares, até das personalidades dirigentes, cuja característica, segundo Marx, depende de cada caso. (Lukács, 1981, p. 246)

52. Ortiz, 1996, p. 23. 
Como mostra o excerto, parecem muito mais complexos, e menos reducionistas, os aspectos gerais da reprodução social em Marx, de modo que reduzir o seu entendimento de mundo a um determinismo forçado não condiz, pelo menos de acordo com os termos ontológicos assinalados por Lukács, com o seu autêntico pensamento.

Pois bem, apesar de não negar em absoluto uma interação com a "dimensão econômica", Ortiz considera totalmente fora de propósito afirmar que "as relações que se estabelecem" no âmbito cultural guardam qualquer tipo de "determinação em última instância", ${ }^{53}$ segundo ele. Apoiando-se em Braudel, o autor diz que "as estruturas do cotidiano" possuem um ritmo e uma condição diferenciada em relação às trocas dos mercados regionais e às transações comerciais internacionais. Segundo Ortiz, o fator preponderante que fez com que a sociedade entre os séculos XV e XVIII comportasse um nível lento de mudanças, preservasse a continuidade, estaria ligado "a uma relativa permanência da esfera propriamente cultural". Diz ele: "Hábitos alimentares, maneira de se vestir, crenças, enfim, os costumes fazem um contrapeso à mobilidade mercantil, confinada ao domínio das trocas internacionais". ${ }^{54}$ Dessa forma, a correlação entre cultura e economia não se faria de maneira imediata (nas palavras dele); a história cultural das sociedades capitalistas, portanto, não se confundiria com as estruturas permanentes do capitalismo. A esfera da cultura se desenvolveria de modo paralelo ou autônomo ao processo econômico, sem depender dele. Se a pós-modernidade hoje se impõe, diz ele, é exatamente pelo fato de que no âmago desse mundo descrito como capitalista surgem "outras configurações irredutíveis ao processo econômico". 55

Ao tratar da determinação social na forma de se alimentar (e mostrar diferentes formas de satisfação da fome ao longo da história), Lukács nos diz que o mercado mundial é o fator objetivo determinante para o desenvolvimento do homem enquanto gênero. Como este não é uma categoria abstratamente geral, muda, mas ao contrário, uma categoria que se torna consciente na sociedade, é somente com a intensificação do mercado mundial que o problema do gênero, como realidade da espécie humana, ascende à ordem do dia como problema universal. "Ora, este processo aparece com muita evidência, diz Lukács, na evolução do modo de pre-

53. Ibidem, p. 23.

54. Ibidem, p. 24.

55. Ibidem, p. 24. 
parar o alimento: o seu caráter é localístico e se integra em unidade lentamente, e em termos muito relativos, até no plano nacional". ${ }^{56}$ É por meio do mercado mundial que o modo de preparar o alimento estrangeiro vai perdendo aquela repugnância inicial verificada e as "cozinhas" de um modo geral vão se internacionalizando, diz ele. Desse modo, seria muito mais amplo o ângulo de análise da conservação e da integração entre as diferentes formas de se preparar o alimento, que, através do mercado mundial, demonstra o grau da incidência que a sociabilidade exerce sobre as diversas formas de se alimentar dos indivíduos.

A problemática cultural, ponto a partir do qual Ortiz se propõe a analisar a realidade mundial, teria em Herder um precursor de uma maneira nova de pensar. Crítico da filosofia de sua época, conta Ortiz, Herder rechaça o "universal", a "humanidade", optando pelas "identidades particulares". Apesar de não dizer como o referido autor chega a tais conclusões, isto é, quais são as bases metodológicas que o fazem concluir inexistir uma "malha histórica global", Ortiz nos diz que as sociedades seriam, dessa maneira, análogas aos organismos vivos, centrados sobre si mesmos. "Cultura existiria apenas no plural, enfoque antagônico à visão abrangente do iluminismo", ${ }^{57}$ diz ele. Ainda segundo esse pensador brasileiro, essa dimensão pluralista permeará a tradição antropológica. "Os estudos comparativos realizados no século XIX, como os de Tylor, tentam mostrar como a mentalidade primitiva difere da do homem moderno", assinala. Nesse sentido, até mesmo o método de observação participante reconhece esse distanciamento e buscará na sua aplicação eliminar tal problema. "Como o observador é um estrangeiro, se encontra 'fora' do ambiente que lhe interessa captar, ele deve dele se aproximar, 'fazer-se nativo' para apreendê-lo de maneira convincente". ${ }^{58}$

Em primeiro lugar, na Ontologia, Lukács afirma que o gênero humano é um gênero em explicitação. $\mathrm{O}$ salto para além da animalidade advindo com o ato de trabalho o fez um gênero não mais mudo em um estágio de manifestação ainda mudo; o ser-para-si do homem no estágio do seu mero ser-em-si. Este paradoxo, para o qual o filósofo húngaro chama a atenção, de acordo com ele só soa dessa forma para aqueles que buscam nas fases do desenvolvimento, e não no processo, captar um movimento que é por essência dinâmico. A diferença dessa argumentação para a anterior, portanto, se evidencia no fato de que as diferenças entre as épocas

56. Lukács, 1981, p. 149.

57. Ortiz, op. cit., p. 20.

58. Ibidem, p. 21. 
que realmente compreendem a história humana fazem parte exatamente do processo pelo qual se explicita o gênero humano.

A junção entre o início e o fim constitui a história mundial da humanidade, a plena explicitação do ser-para-si do gênero humano. Ser-para-si este que só pode se realizar, em termos adequados a si mesmo, de forma consciente: o gênero humano não mais mudo deve, enquanto tal, estar presente também na consciência dos homens. (Lukács, 1981, p. 183)

A respeito dos nexos e dos contrates entre a natureza orgânica e o ser social, Lukács nos diz que a reprodução é comum a ambos. O mutismo da primeira estaria explicado pelo fato de esta não constituir complexos parciais mediadores permanentes entre os seres viventes singulares e o ambiente e, com isso, a interação com este último ser mínima. Disso se explicaria a identidade imediata entre a reprodução ontogenética dos exemplares singulares com a reprodução filogenética. Na sociedade, contudo, a situação é diferente. Por ser fundado a partir da posição teleológica do trabalho, inexistente na natureza, o ser social submete o ambiente a transformações conscientes e desejadas. Nessa interação com o mundo circundante, são constituídos complexos sociais mediadores. A interação com a realidade exterior, portanto, em vez de direta, tem os efeitos retroagidos sobre os indivíduos mediados socialmente. O médium iniludível dessa mediação entre homem e natureza é a sociedade. Ora, como pode então haver certo tipo de "analogia" entre sociedade e organismos vivos se a interação da primeira com o mundo é diferente da segunda, ocorre por meio de complexos sociais mediadores? A concepção de "identidades particulares" também se choca com as diversidades que se verificam no interior do ser social entre aparência e essência. Essas diversidades que separariam a essência do fenômeno, bem como lhes colocariam em forte contradição, na referida leitura estariam totalmente fora de propósito. Citando uma polêmica entre Engels e Feuerbach, Lukács chama a atenção para essa importante distinção entre essência e fenômeno na vida social. Segundo ele, teria replicado Engels a Feuerbach o seguinte sobre uma fala deste último que dizia que somente em casos "anormais", "desgraçados", o ser se separa da essência:

Um belo elogio da situação existente. Exceto casos contra a natureza, poucos casos, anormais, há sete anos, voluntariamente, o porteiro trabalha numa mina de carvão, de sol a sol, catorze horas por dia, e porque este é o teu ser, é também a tua essência... É a tua "essência", a de ser submetido a um ramo de trabalho. (Lukács, 1981, p. 233) 
Na proposta de ecologia cognitiva, o influente pensador contemporâneo Pierre Lévy vai propor um caminho totalmente diverso do tradicional: o da articulação entre elementos heterogêneos - o pensamento individual, as instituições sociais e as técnicas de comunicação - que formariam, segundo ele, coletividades pensantes homens-coisas. Lévy nos diz que a variabilidade e a multiplicidade advinda da pesquisa histórica não conduzirão a uma pura e simples contingência das formas de conhecer, bem como a um relativismo absoluto. Segundo ele, fundado nos estudos sobre as articulações entre os módulos do sistema cognitivo humano e os diversos sistemas semióticos provindos das culturas, é possível delinear como surgem certos tipos de racionalidade. De acordo com ele, como toda ecologia cognitiva se interessa pelas misturas e pelos encaixes fractais de subjetividade e objetividade, esta difere portanto da abordagem kantiana, bem como da proposta por Heidegger. Apesar de não se opor ao questionamento deste último do sujeito consciente, racional e voluntário, Lévy afirma que ao descartar o terreno da metafísica, em vez de substituí-lo por um caminho "vertical", prefere traçar "um percurso em zigue-zague, saltando de uma escala a outra, hipertextual, rizomático", segundo ele, "tão heterogêneo, múltiplo e multicolorido quanto o próprio real". ${ }^{59}$ Sem se preocupar em explicar as premissas metodológicas que o conduziram a tal conclusão (a tal ponto de partida), Lévy assinala então ter conseguido uma metodologia adequada "para prevenir os dualismos maciços" que, em sua opinião, tantas vezes nos dispensam de pensar, inclusive de pensar o próprio pensamento.

[...] espírito e matéria, sujeito e objeto, homem e técnica, indivíduo e sociedade etc. Propomos que estas oposições grosseiras entre essências pretensamente universais sejam substituídas por análises moleculares e a cada vez singulares em termos de redes de interfaces. (Lévy, 1993, p. 134)

Apoiado em pesquisas da psicologia cognitiva, Lévy sustenta a sua argumentação no fato apontado por ela de o sistema cognitivo humano ser composto por múltiplas partes de todos os tamanhos e de todos os tipos, o que retrataria uma figura da mente estilhaçada. Somando-se isso ao fato de parcela significativa dos atos humanos serem automáticos, não passarem pela vontade deliberada, a consciência seria simplesmente "uma das interfaces importantes entre o organismo e seu meio

59. Lévy, 1993, p. 134. 
ambiente". ${ }^{60}$ Para o autor, como o pensamento se dá numa rede na qual "neurônios, módulos cognitivos, humanos, instituições de ensino, línguas, sistemas de escrita, livros e computadores se interconectam, transformam e traduzem as representações", não há mais sujeito ou substância pensante, nem material, nem espiritual. A "novidade" da colocação de Lévy vai perdendo consistência à medida que ele prossegue apresentando o material no qual apoia sua posição. Uma das suas fontes, o autor Michel Serres, por exemplo, ao tentar expor num dos seus livros, conforme assinala Lévy, as relações recíprocas entre sujeitos e objetos, escreve: "[Serres] Mostra como, através da múmia, do cadáver e dos ossos, o objeto nasce do sujeito". ${ }^{61} \mathrm{~A}$ dissolução (puramente abstrata) da cortina de ferro ontológica, conforme assinala duas autoras citadas por Lévy, estaria sendo confirmada por diversas correntes científicas contemporâneas, que estariam incluindo as "noções de singularidade, de evento, de interpretação e de história" nos desenvolvimentos das ciências físicas. Destarte, baseado nos rizomas de Deleuze e Guattari, na recusa da substância por Latour, vão deixar de existir (novamente: abstratamente) as distinções entre coisas e pessoas, sujeitos pensantes e objetos pensados, inerte e vivo. De modo que para Lévy tudo que for capaz de produzir uma diferença numa rede deve ser considerado como um ator; de maneira que a relação dispositivo técnico e homem deve então dessa forma ser pensada:

As máquinas são feitas por homens, elas contribuem para formar e estruturar o funcionamento das sociedades e as aptidões das pessoas, elas muitas vezes efetuam um trabalho que poderia ser feito por pessoas como você ou eu. Os dispositivos técnicos são portanto realmente atores por completo em uma coletividade que já não podemos dizer puramente humana, mas cuja fronteira está em permanente redefinição. (Idem, p. 137)

A ecologia cognitiva seria, então, o estudo das dimensões técnicas e coletivas da cognição, segundo Lévy. O sociólogo Zygmunt Bauman fala que saímos da fase "sólida" da modernidade e adentramos na fase "líquida". Uma fase em que, segundo ele, as organizações sociais responsáveis por assegurar padrões de comportamento aceitáveis não podem mais manter sua forma por muito tempo pelo fato de se decomporem mais rápido que o tempo necessário para se estabelecerem. Vista cada dia mais como uma "rede", e não como uma "estrutura" (ou uma "totalidade

60. Ibidem, p. 135.

61. Ibidem, p. 136. 
sólida"), a sociedade é "percebida e encarada como uma matriz de conexões e desconexões aleatórias e de um volume essencialmente infinito de permutações possíveis" 62 (um enigma!, R. C.). A sociedade "aberta" de agora é uma sociedade exposta aos golpes do "destino", aos efeitos da chamada "globalização negativa"; ela é constituída de indivíduos que vivem horrorizados por sua própria vulnerabilidade. A redução das políticas de seguro contra "os infortúnios individuais", relegando as pessoas a "autorresponsabilidade individual", põe a sociedade exposta à rapacidade das forças que não controla. Na busca então por uma "legitimidade alternativa" para a sua autoridade, o Estado se encontra em condições de oferecer não mais do que proteção pessoal aos cidadãos (das ameaças de um pedófilo à solta, um serial killer, um terrorista, um imigrante ilegal etc.). Bauman apresenta números que apontam que $49 \%$ dos países mais pobres recebem apenas $0,5 \%$ do produto global, $90 \%$ da riqueza se concentra nas mãos de $1 \%$ dos habitantes do planeta, assinala que as ações do governo americano e de seus satélites (OMC, FMI e Banco Mundial) geraram, obliquamente, o nacionalismo, o fanatismo religioso, o terrorismo. Ele diz que as políticas antiterror aplicadas nos EUA e na Europa tiveram como função latente mudar a localização da autoridade do Estado (cita de um pesquisador que a $\mathrm{Al}$ Qaeda até 2001 sequer tinha um nome) e aponta que, diante dessa desastrada política antiterror, ganham crédito as teses de que interesses comercias estariam dando o tom da propagação do medo e do seu combate (cita inclusive documentação que comprovaria o aumento do lucro dos produtores e comerciantes norte-americanos com produtos e dispositivos de autodefesa).

Outro autor influente no debate contemporâneo é o sociólogo Stuart Hall. Ele sustenta que após ter surgido junto com a modernidade o chamado sujeito "centrado", a fase que compreende a segunda metade do século XX - a modernidade tardia - é marcada pelo descentramento do sujeito moderno. Ou seja, antes de se tornarem deslocadas, as identidades eram "unificadas e coerentes". Tendo libertado os indivíduos de seus apoios estáveis nas tradições, as transformações associadas à modernidade trouxeram consigo o nascimento do "indivíduo soberano", concepção que teria sido fortalecida com os movimentos da reforma e do protestantismo, do humanismo renascentista, do iluminismo. A ênfase no indivíduo, ratificada com o sujeito cartesiano de Descartes - a capacidade para raciocinar e pensar do sujeito individual - e pela definição de identidade contínua de Locke ligada à experiência pessoal, só viria a se atenuar com o advento das ciências sociais, que pas-

62. Bauman, 2007, p. 9. 
saram a situar esse cidadão individual no interior das grandes estruturas sustentadoras da sociedade moderna. O descentramento final do sujeito cartesiano na segunda metade do século XX seria, portanto, decorrência de alguns avanços na teoria social. A leitura de Althusser sobre Marx seria um destes. Ele poderia ter até alguma razão quando afirmou que Marx não se valeu de uma noção abstrata de homem, ou mesmo desfez o mito do indivíduo como "sujeito da economia clássica", mas para Hall a negativa de uma essência humana universal (na leitura feita por Althusser) teve fortes repercussões. Porém o dano maior às "noções" de sujeito e identidade "fixos" e "estáveis" talvez venha da descoberta do inconsciente por Freud e dos estudos psicanalíticos de Lacan. De acordo com Hall, a formação de nossas identidades, da estrutura dos nossos desejos, para Freud, são baseadas em processos psíquicos e simbólicos do inconsciente, e funcionam segundo uma "lógica" muito diferente daquela da razão. A formação do eu no "olhar" do outro, segundo Lacan, que inicia a relação da criança com os sistemas simbólicos fora dela mesma, ${ }^{63}$ na primeira infância, é uma fase marcada por sentimentos contraditórios e não resolvidos, aspectos-chave da "formação inconsciente do sujeito", que irão permanecer com a pessoa por toda a vida. Apesar de partido, o sujeito vivencia sua identidade como se tivesse unificada, "como resultado da fantasia de si mesmo como uma 'pessoa' unificada" ${ }^{44}$ formada na fase do espelho (essa seria a origem contraditória da identidade). Já que existe sempre algo fantasiado sobre sua unidade, a identidade permanece sempre incompleta, "está sempre 'em processo"'. Como os processos inconscientes não são facilmente postos à prova, eles têm sido objeto de muitos questionamentos. Mas, apesar disto, segundo Hall, seu impacto sobre as formas modernas de pensamento são indiscutíveis.

\section{Conclusão}

As mudanças no mundo contemporâneo, inclusive as descobertas no meio científico, têm impulsionado novos rumos, como vimos, ao pensamento social

63. De acordo com Lacan, naquilo que ele chama de "fase do espelho", a criança que ainda não tem nenhuma autoimagem como uma pessoa "inteira", "se vê ou se 'imagina' a si própria refletida — seja literalmente, no espelho, seja figurativamente, no 'espelho' do olhar do outro - como uma 'pessoa inteira"” (Hall, 2000, p. 37).

64. Ibidem, p. 38. 
moderno. A razão para a emergência daquilo que tem se chamado pós-modernidade está associada a uma série de fatores. O professor André Lemos, por exemplo, aponta o aparecimento da ideia de pós-modernidade para a segunda metade do século XX, momento em que ganham força os mass media e a sociedade de consumo. O declínio das grandes ideologias modernas, também assinalado por Bauman, e de ideias como a de "progresso" terão profundas repercussões nos campos da economia, ciência, tecnologia etc. O colapso do pensamento, do planejamento e da ação a longo prazo e o desaparecimento das estruturas nas quais estes poderiam ser traçados com antecedência têm levado a um desmembramento da história política e das vidas individuais em uma série de episódios de curto prazo. "Uma vida assim fragmentada estimula orientações 'laterais', mais que 'verticais", diz Bauman. O aparecimento duma nova ordem econômica, segundo Lemos, denominada pós-industrialismo, seria um desses marcos do processo de mudança social e cultural denominado pós-modernidade.

O pós-industrialismo corresponderia, por um lado, à diminuição dos trabalhadores no setor secundário da economia e, por outro, ao acréscimo destes no setor de serviços. Na fase pós-industrial da sociedade de consumo, a produção de bens e serviços (ligados a grandes consumos de energia) seria modificada conforme as novas tecnologias da informação. Contudo, ela não representaria uma ruptura com a dinâmica monopolista de capitalismo, mas uma radicalização do desenvolvimento de sua lógica. Já Ortiz argumenta que a sociedade pós-industrial seria constituída pelo conjunto tecnocientífico formado pela microeletrônica, pela engenharia genética e pela energia nuclear. A recorrência ao "pós" estaria ligada ao fato de a compreensão dessa nova configuração social estar em aberto. Todas essas tentativas de entendimento teriam em comum a ênfase nas tecnologias de ponta no processo de organização da produção fabril. As unidades dispersas de produção deveriam sua existência a essas tecnologias, que seriam as responsáveis por um "novo modo de industrialização", distinto do fundado pelo vapor, petróleo. Nessa nova articulação social, portanto, o consumo, o poder, a produção e as relações sociais se encontrariam cada vez mais descentralizados. É preciso que se diga que há pesquisas que encaram essas transformações de outra forma, como a de D. Harvey, R. Antunes, L. Vasapollo, a do próprio ex-assistente de Lukács, I. Mészáros, bem como muitas outras associadas à sociologia do trabalho.

De modo geral, o que tem se percebido na forma de analisar as transformações em curso é a perda do paradigma ontológico do trabalho, ou da centralidade 
do trabalho, como referência no exame de tais eventos. A opção pelos estudos "dos sistemas semióticos fornecidos pela cultura", pelo entendimento de todo processo como interfaceamento, pelos estudos culturais e pelo multiculturalismo, tem se sobressaído e orientado a maioria das pesquisas. Carlos Nelson Coutinho (2006) afirma que a recusa em compreender a totalidade pelo pós-modernismo revela um caráter irracionalista, enquanto o fetichismo da técnica hoje tão em moda revela uma razão posta a serviço da instrumentalidade. Junto com o neoliberalismo, se volta para a despolitização geral da sociedade e, por conseguinte, da cultura; para o pós-modernismo, os "grandes relatos" estão superados, não têm mais sentido e levam ao totalitarismo, e, em vez de as lutas serem travadas em prol de valores universais, estas devem se voltar para a afirmação das identidades e das diferenças. ${ }^{65}$

Dentre as tendências apresentadas na abordagem aqui desenvolvida, poderíamos destacar, por exemplo, a absoluta negação das diferentes legalidades das esferas do ser em geral, isto é, que a continuidade na natureza inorgânica se caracteriza pelo "tornar-se outro", a natureza orgânica pela "troca" com a natureza inorgânica (independente ontologicamente das outras) e o ser social pela posição teleológica do trabalho, inexistente no ser natural. Lévy acusa as grandes dicotomias, como a de sujeito e objeto, de nos impedir de reconhecer que "todos os agenciamentos cognitivos concretos" são, para ele, constituídos por "ligas, redes, concreções provisórias de interfaces" e que, por conta disso, pertencem aos dois lados "das fronteiras ontológicas tradicionais". A questão da "troca orgânica", colocada por Lukács, é totalmente desconsiderada e, em certo sentido, vulgarizada. A dialética entre "vontade consciente" e o que vem nos homens "produzido espontaneamente pelo desenvolvimento" deve, indubitavelmente, ser levada em conta nas análises sobre o inconsciente freudiano e os estudos psicanalíticos de Lacan. $O$ não entendimento da técnica como momento parcial do desenvolvimento, e sim como fato autônomo, que culmina no seu fetiche, faz com que leituras como "conectar computadores ao cérebro" deixem de ser entendidas exclusivamente como recuo das barreiras naturais. Por fim, não se pode deixar de considerar que a modernidade, cuja caracterização passa antes de tudo pelas relações de assalariamento, antes de ser superada,

65. Num texto seminal e considerado clássico na literatura brasileira, O estruturalismo e miséria da razão, Carlos Nelson Coutinho analisa, à luz de Lukács, a trajetória da filosofia burguesa nas suas variantes do irracionalismo e da "miséria da razão". Tal texto ganhou uma nova edição pela Editora Expressão Popular, São Paulo, ano 2010. 
precisa resolver o nódulo concreto que ainda faz do valor de uso da força de trabalho, em muito negado pelo pós-industrialismo, a base do sistema, de apropriação, direta e indireta, do excedente produtivo.

\section{Recebido em 17/7/2012 - Aprovado em 11/3/2013}

\section{Referências bibliográficas}

BAUMAN, Z. Tempos líquidos. Rio de Janeiro: Jorge Zahar, 2007.

CASTRO, R. A reprodução social na ontologia de Lukács: um escólio introdutório. Dissertação (Mestrado) - Faculdade de Serviço Social, Universidade Federal de Alagoas, Maceió, 2011.

. Notas preliminares sobre a teoria do valor. In: COSTA, G.; PRÉDES, R.; SOUZA, R. (Orgs.). Crise contemporânea e Serviço Social. Maceió: Edufal, 2010a.

O problema da emancipação e da liberdade. Em Pauta: Teoria social e realidade contemporânea, UERJ, Rio de Janeiro, v. 7, n. 25, 2010 b.

COUTINHO, C. N. Intervenções: o marxismo na batalha das ideias. São Paulo: Cortez, 2006.

HABERMAS, Jurgen. Teoría de la acción comunicativa. Madri: Taurus, 1987.

HALL, S. A identidade cultural na pós-modernidade. 4. ed. Rio de Janeiro: LP\&A, 2000.

IAMAMOTO, Marilda. A prática como trabalho e a inserção do assistente social em processo de trabalho. 7. ed. São Paulo: Cortez, 2004.

Serviço Social em tempo de capital fetiche: capital financeiro, trabalho e questão social. São Paulo: Cortez, 2007.

LEMOS, A. Cibercultura, tecnologia e vida social na cultura contemporânea. 3. ed. Porto Alegre: Sulina, 2007.

LESSA, S. Mundo dos homens: trabalho e ser social. São Paulo: Boitempo, 2002. . Para compreender a ontologia de Lukács. 3. ed. Ijuí: Ed. Unijuí, 2007.

; PINASSI, M. O. (Orgs.). Lukács e a atualidade do marxismo. São Paulo: Boitempo, 2002. 
LÉVY, P. As tecnologias da inteligência: o futuro do pensamento da era da informática. Rio de Janeiro: Editora 34, 1993.

LUKÁCS, G. La riproduzione. In: . Per una ontologia dell'essere sociale. Roma:

Riuniti, 1981. v. II.

NETTO, J. P. Lukács: o guerreiro sem repouso. São Paulo: Brasiliense, 1983.

ORTIZ, R. Mundialização e cultura. São Paulo: Brasiliense, 1996.

TONET, I. Educação, cidadania e emancipação humana. Ijuí: Ed. Unijuí, 2005. 